\title{
EXERCISING OPTIONS TO REPURCHASE EMPLOYEE-HELD STOCK: A QUESTION OF GOOD FAITH
}

WITHIN the context of the close corporation, options to repurchase employeeowned stock present an opportunity for abuses that are likely to escape judicial correction. ${ }^{1}$ Because a repurchase agreement is designed primarily to induce a valuable employee to remain with the company issuing the shares in question, ${ }^{2}$ an exercise of the option is almost always conditioned on termination of the employment relationship. 3 Usually, the option runs to the corporation or to certain shareholders. ${ }^{*}$ It may last until the employee's retirement or death, ${ }^{5}$ although occasionally it expires after a term of years, the employee then receiving unrestricted ownership of the stock. ${ }^{6}$ While some agreements stipulate

1. The close corporation is usually defined as one with relatively few shareholders, close identity between ownership and management and little or no public trading in its shares. See Sympositmm-The Close Corporation, 52 Nw. U.L. Rev. 345-47 (1957). Because share ownership by "outsiders" not actively connected with the business is considered undesirable, various restrictions on the transfer of stock are frequently adopted, among them options to repurchase on a stated contingency. O'Neal, Restrictions on Transfer of Stock in Closely Held Corporations: Planning and Drafting, 65 HARv. L. Rev. 773-76 (1952). These options are infrequently employed by large, publicly-held corporations, for the active public trading makes the restriction of "outsider" entrance unfeasible. See NAtional Industrial Conference Bd., Studies in Personnei Policy No. 132, Stock Ownership Plans for Workers 19 (1953). See also Washington \& Rothschild, Compensating tae Corporate Executive 503-42 (rev. ed. 1951) [hereinafter cited as Washingron \& RoTHschiLD]. In any event, the percentage of outstanding shares held by a single employee in a publicly owned corporation will usually be so small that little temptation for abuse cxists. See National Industrala Conference Bd., op. cit. supra at 12 ; Washington \& Rotuschind 138. Accordingly, this Note will focus on the closely-held corporation.

Also, the Note, though frequently relevant to "buy-sell" agreements (binding obligations to repurchase) or first-refusal arrangements, will not discuss them as such. A leading case involving "buy-sell" agreements is Fleitmann v. John M. Stone Cotton Mills, 186 Fed. 466 (5th Cir. 1911). For the right of first refusal, see Lawson v. Household Fin. Corp., 17 Del. Ch. 343, 152 Atl. 723 (Sup. Ct. 1930). See also Palmer v. Chamberlin, 191 F.2d 532 (5th $\mathrm{Cir}$. 1951) (first-refusal provision combined with repurchase option).

2. Harker v. Ralston Purina Co., 45 F.2d 929, 930 (7th Cir. 1930), cert. denied, 284 U.S. 619 (1931). See generally O'Neal, supra note 1, at 807 .

3. See, c.g., the agreements litigated in Palmer v. Chamblerlin, 191 F.2d 532 (5th Cir. 1951); Lawrence v. Sudman, 70 F. Supp. 387 (S.D.N.Y. 1945); Arensten v. Sherman Towel Serv. Corp., 352 Ill. 327, 185 N.E. 822 (1933).

4. O'Neal, supra note 1, at 792-95. Sometimes the option may run to a trust, NATionaL

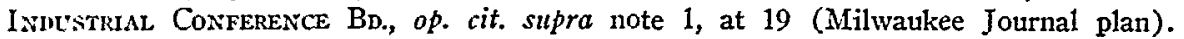
Presumably, any legal entity with power to transfer stock could retain a repurchase option.

5. See, c.g., cases cited note 3 supra.

6. See, e.g., Harker v. Ralston Purina Co., 45 F.2d 929 (7th Cir. 1930), cert. denied, 284 U.S. 619 (1931) (five-year term). Such an option is less useful to the closely-held corporation than one which runs indefinitely. It might be adopted by promoters who anticipated that the corporation's shares would become publicly traded and who wanted to attract an employee with the prospect of capital gains. 
a fixed repurchase price, ${ }^{7}$ most utilize a pricing mechanism which either looks to an extrinsic standard, such as book value, ${ }^{8}$ or (less often) leaves the terms of repurchase to the corporate party in interest. ${ }^{9}$ Frequently, however, the intrinsic value of the stock ${ }^{10}$ rises substantially above the price that the option holder would be required to pay. ${ }^{11}$ Since in this situation dominant shareholders can increase the per-share worth of their holdings by reacquiring (or having the corporation reacquire) the stock of an employee at less than fair value, the dominant group may find it advantageous to discharge him. ${ }^{12}$

7. See, e.g., W. O. Barnes Co. v. Folsinski, 337 Mich. 370, 60 N.W.2d 302 (1953).

8. Book value is the most frequently used formula. O'Neal, supra note 1, at 798-99. Other methods of computation which provide for capital appreciation include fixed price subject to renegotiation, capitalization of earnings, and appraisal. Id. at 800-04. For an agreement utilizing a combination of book value, capitalization of earnings, and appraisal, see Abbott v. Abbott Motors, Inc., 113 N.Y.S.2d 213 (Sup. Ct. 1951).

9. Krauss v. Kuechler, 300 Mass. 346, 15 N.E.2d 207 (1938) (price to be set by remaining stockholders) ; New Eng. Trust Co. v. Abbott, 162 Mass. 148, 38 N.E. 432 (1894) (price to be set by board of directors).

10. Intrinsic value is derived from such factors as earning power, liquidation value, control value, the corporation's competitive position in its field, and the market price (if available) of stock in similar corporations. See generally Eisele, Valuation of Closcly Held Stocks, 5 W. REs. L. REv. 37, 42-47 (1953).

11. This occurs because repurchase price-fixing methods currently in use do not yield intrinsic value at time of sale. In a period of inflation, book value-net asset value per share -is rarely accurate because assets are generally understated on the balance sheet. More important, the balance sheet does not reflect earning power. Indeed, for many corporations, the balance sheet means nothing in terms of value to an investor. 1 Dewing, The Financial Policy of Corporatrons 530 (5th ed. 1953) [hereinafter cited as Dewing]. Book value is an extremely unreliable indicator of the market price of publicly traded stock. Johnson, Shapiro \& O'Meara, Valuation of Closely-Held Stock for Federal Tax Purposes: Approach to an Objective Method, 100 U. PA. L. Rev. 166, 170 (1951). An option price left to the discretion of the option holder would be likely to approach intrinsic value if high standards of good faith obtained. In practice, however, the holder enjoys considerable latitude for indulging his self-interest. See Krebs v. McDonald's Ex'x, 266 S.W.2d 87 (Ky. 1953) ; Krauss v. Kuechler, 300 Mass. 346, 15 N.E.2d 207 (1938). A fixed price subject to renegotiation will produce current intrinsic value only if negotiations have been carried on recently and in good faith. See Helms v. Duckworth, 249 F.2d 482 (D.C. Cir. 1957).

If, on the other hand, the value of the stock is below the option price, the option holder faces a difficult decision. Failure to exercise within a reasonable time after termination or death will free the stock from restrictions under most options. See Cataldo, Stock Transfer Restrictions and the Closed Corporation, 37 VA. L. REv. 229, 233 (1951). But exercise will necessitate paying more for the stock than it is worth. If, however, the pricevalue differential is small, the option holder should be willing to pay the extra price to keep the stock in friendly hands. And if the differential is large, the option holder is in a favorable position to negotiate for a lower price in view of the restricted market for the stock.

12. For example, in a three-man corporation with shares distributed equally, the retirement of the stock of one would increase the relative holding of the others by $162 / 3 \%$. The actual increase in value of their holdings would depend on how much assets were decreased by the purchase, and on the increased earning power of their $50 \%$ interests.

Some agreements contemplate that the reacquired stock will be resold to another employee at the option price. See, e.g., Palmer v. Chamberlin, 191 F.2d 532 (5th Cir. 1951); 
Despite the fact that the employee may thus be deprived of legitimate expectations, the courts, without inquiring into underlying equities, almost uniformly uphold the exercise of close-corporation options to repurchase. ${ }^{13}$

Most courts regard repurchase options as restraints on alienation, but enforce them if the restraints are reasonable. The prevailing view is that such an option meets this requirement if limited in time once the employee's shares become subject to repurchase. ${ }^{14}$ Whether the price actually paid by the option holder enables him to derive windfall gains is not considered a policy determinant. ${ }^{15}$ Indeed, although dicta indicate that the price must not be so inadequate as to suggest fraud or constitute a forfeiture, ${ }^{16}$ options have never been judicially invalidated solely on this ground. ${ }^{17}$ Rather, because of the difficulties involved in ascertaining a more accurate valuation for close-corporation stock, the courts have been adamant in their refusal to look behind an agreement's pricing formula. ${ }^{18}$

National Industrial Conference BD., op. cit. supra note 1, at 19 (Milwaukee Journal plan). Though the corporation realizes no apparent pecuniary benefit from this transaction, it may be securing a latent financial advantage through the shifting of share ownership to a more valuable employee. In any event, the ultimate purchaser may be said to realize a gain if the stock's earning power is high in relation to its price. Of course, if the reacquired shares are resold for more than the option price, the option holder is profiting at the employee's expense.

13. E.g., Lawrence v. Sudman, 70 F. Supp. 387 (S.D.N.Y. 1945) (plaintiff discharged on Friday, rehired on Monday after stock repurchase) ; Arentsen v. Sherman Towel Serv. Corp., 352 III. 327,185 N.E. 822 (1933) (reasons for discharge not clear). But cf. Ingalls Iron Works Co. v. Ingalls, 256 Ala. 124, 53 So. $2 d 847$ (1951) ; Brown v. Little, Brown \& Co., 269 Mass. 102, 168 N.E. 521 (1929) (option on "retirement" inapplicable when employee discharged). When the stockholder has retired or died the option is almost always enforced. See, e.g., Palmer v. Chamberlin, supra note 12 (citing cases).

14. Palmer v. Chamberlin, 191 F.2d 532, 537-38 (5th Cir. 1951); Missouri ex rel. Huffman v. Sho-Me Power Co-op., 356 Mo. 832, 204 S.W.2d 276, 280 (1947); Allen v. Biltmore Tissue Corp., 2 N.Y.2d 534, 141 N.E.2d 812, 161 N.Y.S.2d 418 (1957). The time limit on exercise of the option after termination of employment is, at most, six months. Cataldo, supra note 11, at 233.

In Greene v. E. H. Rollins \& Sons, 22 Del. Ch. 394, 2 A.2d 249 (Ch. 1938), the court held a repurchase option void as a restraint on alienation unless the corporation could show "special facts" making the option necessary. The case appears to have little precedent value, first, because the option ran for an unlimited time after termination of employment, and second, because most closely-held corporations could probably establish the requisite "special facts." Compare Lewis v. H. P. Hood \& Sons, 331 Mass. 670, 121 N.E.2d 850 (1954) (rejecting the Grecne rationale).

15. See Allen v. Biltmore Tissue Corp., supra note 14. In fact, using a low price in relation to market value has been judicially approved. Harker v. Ralston Purina Co., 45 F.2d 929, 930 (7th Cir. 1930), cert. denied, 284 U.S. 619 (1931).

16. See, e.g., New Eng. Trust Co. v. Abbott, 162 Mass. 148, 154, 38 N.E. 432, 434 (1894), quoted in Palmer v. Chamberlin, 191 F.2d 532, 541 (5th Cir. 1951).

17. But cf. Hardin v. Rosenthal, 213 Ga. 319, 98 S.E.2d 901 (1957) (option to purchase at "market value or true value" too vague to be specifically enforced).

18. See, e.g., Allen v. Biltmore Tissue Corp., 2 N.Y.2d 534, 141 N.E.2d 812, 161 N.Y.S.2d 418 (1957). 
As presently conceived, then, many options contain latent potentialities for the inequitable treatment of the employee. Were he dismissed just before an unusual corporate opportunity reached fruition, or immediately preceding liquidation and the distribution of undervalued assets, ${ }^{10}$ his potential share of the resulting gains could be channeled to the remaining shareholders. Or else, if the option price were book value, the repurchase price could be artificially lowered through the manipulation of balance sheet valuations. ${ }^{20}$ More often, termination would be prompted by a desire to secure the optionee's interest either in high profits or in the enhanced market value of corporate assets. ${ }^{21}$ Occasionally, his dismissal might stem not from pecuniary motives but from an attempt to assemble a controlling block of shares. ${ }^{22}$ Whatever the abuse, ${ }^{23}$ it will be most apparent if the option runs for a limited time and the employee is discharged

19. See Lawrence v. Sudman, 70 F. Supp. 387 (S.D.N.Y. 1945).

20. See note 11 supra. Particularly susceptible to manipulation are various contingency and valuation reserves. Although capricious entries in these accounts are condemned, decisions concerning them are necessarily within management's discretion. 1 Dewing 635; see, e.g., Krauss v. Kuechler, 300 Mass. 346, 15 N.E.2d 207 (1938) (bad-debt reserve). Current accounting practice favors classifying most contingency reserves as part of the shareholder's equity. Axrerican Institute of Accountants, Restatensent and Revision of Accounting Bulletins, Bulz. No. 43, at 43 (1953). To the extent that this practice is followed, it would appear that chances for lowering book value through the use of contingency reserves is lessened. Depreciation reserves also keep values artificially low, as some industries make a practice of relatively fast write-offs. See, c.g., Lawrence v. Sudman, stupra note 19, at 397. Furthermore, many businesses took advantage of the five-year write-offs for emergency facilities available during World War II and the Korean conflict. See generally Bitrrer, Federaz Income Estate and Gift TAXATron 268 (2d ed. 1958); Schlaifer, Butters, \& Hunt, Accelerated Amortization, Harv. Bus. Rev., May 1951, p. 113 ; cf. Paton, Mleasuring Profits Under Infation Conditions: A Serious Problem for Accountants, 89 J. Accountancr 16 (1950).

An option price set at par value could be reduced by reducing par. And a fixed repurchase price could be lowered by consolidating shares. See Ballantine, Corporations $\S 208$, at 483 (1946).

21. Compare 1 Dewing 287.

22. This would most likely happen in the close-corporation context if the directors had an opportunity to transfer a controlling block to an outsider and needed the employce's shares to meet their sales commitments. See Leech, Transactions in Corporate Control, 104 U. PA. L. Rev. 725, 730-32 (1956). Although a minority stockholder who suffers from a transaction of this type has a remedy for fraud, Schroeder v. Carroll, 192 Wis. 460, 212 N.W. 299 (1927), or may sue under SEC Rule X-10B-5, 17 C.F.R. \& $240.10 b-5$ (1949), see Kardon v. National Gypsum Co., 73 F. Supp. 798 (E.D. Pa. 1947), the employee forced to sell after an arbitrary discharge may not be protected, Lawrence v. Sudman, $70 \mathrm{~F}$. Supp. 387, 394 (S.D.N.Y. 1945) ("cases involving purchases by majority stockholders of stock from minority stockholders are not controlling").

23. In addition to the foregoing, a partial exercise of the option is also possible under some option contracts. See, e.g., Palmer v. Chamberlin, 191 F.2d 532, 535 (5th Cir. 1951). Partial exercise might be deliberately undertaken to force down the price on the employee's remaining shares, or might occur merely because sufficient funds were not available to purchase the entire employee-owned block. If the corporation is legally able to purchase all the stock, an "all or nothing" clause could usually be implied and the contract enforced accordingly. 
shortly before he would have acquired unrestricted ownership of the stock. ${ }^{24}$ Even if his shares would have been subject to repurchase indefinitely, discharge would deprive him of future dividends and-when the pricing formula comprehends increases in value-prospective capital gains.

Aryuably, the employee should be estopped from complaining when the repurchase option is exercised to his disadvantage, since, according to the courts, the terms of such an option are presumed to be the product of free, arm's-length bargaining. ${ }^{25}$ To be sure, whether an apparently unfair repurchase is in fact abusive depends on the original expectations of the parties. ${ }^{26}$ And the employee may have actually assented to unfavorable pricing provisions in order to acquire otherwise unavailable stock. He may also have taken the risk of arbitrary corporate action into account when agreeing to both the option price and his salary terms.

Realistically viewed, however, the judicial assumption of free, arm's-length hargaining appears unsound. Entrepreneurs launching a new enterprise may adopt a valuation clause with little thought given to its subsequent operation. ${ }^{2 \pi}$ Frequently, the option is not embodied in the employment contract but is constructively imposed upon it by a charter provision which binds the employee through a brief and usually obscure reference appearing on his stock certifi-

24. In the employee-pension field, courts view suspiciously an arbitrary termination of employment just before an employee reaches the "point of advantage" under the pension plan. Wallace v. Northern Ohio Traction \& Light Co., 57 Ohio App. 203, 210, 13 N.E.2d 139, 142-43 (1937) (dictum), quoted in Gorr v. Consolidated Foods Corp., 91 N.W.2d 772, 783-84 (Minn. 1958).

25. See Palmer v. Chamberlin, 191 F.2d 532, 541 (5th Cir. 1951) ; Lawrence v. Sudman, 70 F. Supp. 387 (S.D.N.Y. 1945) ; Arentsen v. Sherman Towel Serv. Corp., 352 I1l. 327, 185 N.E. 822 (1933) ; cf. Krebs v. McDonald's Ex'x, 266 S.W.2d 87 (Ky. 1953).

26. Theoretically, the employee could contract away all his rights as a shareholder. The relevant inquiry is not whether an agreement is a restriction on alienation but whether the situation before the court was the intended result of the agreement actually made. When an arbitrary dismissal is not involved, the question is whether the price offered is the intended one. See Moser v. Keller, 303 S.W.2d 135 (Mo. 1957), where the words "book value as shown on the books of the bank" were interpreted to mean the value that would have been shown if the books had been kept consistently and correctly. The Moser court undertook a complete analysis of the balance sheet and made an adjustment of approximately $\$ 105,000$ in favor of the plaintiffs, who were shareholders of a trust which owned the repurchased bank. See also Revloc Supply Co. v. Troxell, $281 \mathrm{~Pa}$. 424, 126 Atl. 774 (1924), where specific performanice was denied an option holder because the contract showed an intent that the employee share in the surplus that accumulated during his period of employment, and because enforcement at par value following only two small dividends would violate intent.

When the employee has been dismissed, determination of intent poses difficult problems, since the termination itself will practically always be within the legitimate scope of corporate power. See 2 Fletcher, Private Corporations $\$ 353$ (1954). For a proposed solution to these problems, see text accompanying notes 34-35 infra.

27. The deceptive simplicity of book value probably accounts for its popularity. O'Neal, supra note 1, at 799. The forms for repurchase contracts cited in 2 FletCHER, Corporation: Forms ANNOTATEd $\$ \$ 1712-14$ (3d ed. 1958), utilize only par and book value. 
cates. ${ }^{28}$ Alternatively, a bylaw amendment assented to by inadequately informed shareholders may have created the right to repurchase. ${ }^{29}$ Even when the option is fully set out in an employment contract or a special agreement, a desire to establish or maintain intrafirm camaraderie may prevent the employee, however highly placed, from demanding explicit safeguards against reacquisition-motivated dismissal. ${ }^{30}$ The less sophisticated employee may take eager advantage of an opportunity to obtain stock without realizing that his job will hecome less secure should his fellow shareholders seek to enhance their holdings following an appreciation in the stock's value. And other employees, not suspecting that significant gains might lead to an exercise of the option, may have accepted employment largely in the hope of speculative profits on the stock. ${ }^{31}$ Thus, in a number of instances, options to repurchase might be meaningfully classified as contracts of adhesion.

Furthermore, the optionee's status as shareholder entitles him to greater judicial protection than he receives. In other contexts, directors or majority stockholders taking action adverse to minority interests are held to rigorous standards of good faith and full disclosure. ${ }^{32}$ In the instant situation, the optionee, having committed his time and ability to the corporation in return for partial compensation in shares, should be accorded similar safeguards. Equityinterest remuneration necessitates his bearing a risk of loss incommensurate with his position as an employee. ${ }^{33}$ Though his rights as a stockholder are

28. See Lewis v. H. P. Hood \& Sons, 331 Mass. 670, 121 N.E.2d 850 (1954); cf. Weissman v. Lincoln Corp., 76 So. $2 d 478$ (Fla. 1954) (reference to minute book setting out stockholder's agreement held sufficient notice to creditor) ; Allen v. Biltmore Tissue Corp., 2 N.Y.2d 534, 141 N.E.2d 812, 161 N.Y.S.2d 418 (1957) (incorporating restriction by reference to bylaws meets requirements of the UNIFORM Stock Transfer ACr \& 15, N.Y. Pers. Prop. Law \$ 176).

29. See Hornstein, Stockholders' Agreements in the Closely Held Corporation, 59 YALE L.J. 1040, 1041 (1950). A satisfactory agreenent of this type requires careful planning and drafting. See generally Ness, Federal Estate Tax Consequences of Agreements and Options To Purchase Stock on Death, 49 CoLum. L. Rev. 796 (1949); O'Neal, supra note 1 , at 773-816. Since close-corporation stockholders are frequently not in a position to understand all the ramifications of such an agreement, courts should be hesitant to conclude that the shareholders intended the agreement to subordinate the interests of the optionees to the dominant shareholders ${ }^{*}$ personal profit.

30. One leading treatise's analysis of the bargaining situation indicates that the executive's protection against changing conditions usually lies in later renegotiations rather than in specific contractual provisions. Washington \& RothschiLd 36; see generally id. ch. 2. Thus, even an exxecutive in a seemingly strong position may rely to a large extent on corporate good faith.

31. Such contracts are not uncommon when the business is new or not in a position to commit itself to regular salary payments high enough to interest a key employee. See id. at 122 n.6.

32. See Perlman v. Feldmann, 219 F.2d 173 (2d Cir. 1955), cert. denied, 349 U.S. 952 (1955) ; Lebold v. Inland Steel Co., 125 F.2d 369 (7th Cir. 1941), cert. denied, 316 U.S. 675 (1942) ; Kardon v. National Gypsum Co., 73 F. Supp. 798 (E.D. Pa. 1947) ; Sympositum -The Close Corporation, 52 Nw. U.L. Rev. 345, 395 n.51 (1957).

33. First, any return on his stock depends on the declaration of dividends, which in turn depends on profits and the directors' discretion. Ballantine, Corrorations $\S 231$ 
limited by the repurchase agreement, vesting him with shareholder status is not a subordinate part of the agreement but underlies its essential purpose-to retain key employees. ${ }^{34}$ When, therefore, the option serves not as an incentive to continued employment but as an inducement leading to the opposite resultdischarge of the optionee by an option holder seeking to reacquire stock-a prior understanding that the option could be exploited solely for the personal gain of dominant shareowners should not be assumed. The courts should instead require the option holders to show that, at the outset, the employee was made aware of, and assented to, this possible use of the option. Similarly, if interested parties have control over the pricing mechanism, they should be held to a high standard of good-faith dealing, absent clear evidence of knowing consent to their untrammeled discretion. ${ }^{35}$

Adopting a good-faith approach, a court would first determine whether an abuse had in fact occurred. Retirement, death, voluntary resignation, or discharge for business reasons may cause an option to be exercised at a disadvantageous but not necessarily unfair time for the employee. Given such a cause,

(1946). If the corporation meets with financial reverses, it probably will not or cannot exercise the repurchase option. See, c.g., Palmer v. Chamberlin, 191 F.2d 532, 542 (5th Cir. 1951) (option to repurchase not exercised during depression); N.Y. PEN. LAw \$ $664(5)$ (director who votes to purchase shares except out of surplus is guilty of misdemeanor). If the company goes bankrupt, a claim for wages enjoys priority up to $\$ 600$ per employee under the Bankruptcy Act $\$ 64$ (a) (2), 52 Stat. 874 (1938), as amended, 11 U.S.C. $\$ 104$ (1952), and recent wage claims will not be discharged if funds are unavailable to pay them, Bankruptcy Act $\S 17$ (a) (5), 52 Stat. 851 (1938), as amended, 11 U.S.C. $\S$ 35 (1952). But the employee-shareholder may find that he has no claim in either contract or quantum meruit for the money he has invested. In re Tichenor-Grand Co., 203 Fed. 720 (S.D.N.Y. 1913). Any attempt to recover in quantum meruit for work performed will run into difficult problems of statutory and contract interpretation, as the bankruptcy provisions apply specifically to wages. Although this may not prevent quantum meruit claims in some cases, the employee who elects to take compensation in dividends may be said to take the risk of the corporation's failure to prosper and thus, in effect, to have agreed to work for nothing in excess of his stated salary. See Arentsen v. Sherman Towel Serv. Corp., 352 Ill. 327,185 N.E. 822 (1933).

34. See Harker v. Ralston Purina Co., 45 F.2d 929, 930 (7th Cir. 1930), cert. denied, 284 U.S. 019 (1931). Repurchase agreements are also made in the hope that the valuation will be conclusive for estate tax purposes. Tarleau, Tax Problens in the Valuation of Property, 25 TAxes 520, 522 (1947). Or the price may be kept low to ensure liquidation of an umployee's estate. Ness, supra note 29 , at 815 . None of these purposes is served when the corporation arbitrarily terminates employment to reacquire stock.

35. Cf. Uniform Commercial Cone $\$ 2-305$ (2). The section legalizes mercantile contracts in which price is fixed by a party in interest. It imposes a requirement that price be set in good faith-i.e., "honesty in fact," \$1-201(19), and enjoins merchants to adhere to reasunable commercial standards of fair dealing, $\$ 2-103(1)(\mathrm{b})$. Although the parties to a repurchase option are not merchants, the transaction appears sufficiently analogous to tuggest applying similar standards. Since accepted valuation principles exist in the stock transfer field, see 1 Dewing 281-308, courts which require good faith of interested pricefixers, see, i.g., Krauss v. Kuechler, 300 Mass. 346, 15 N.E.2d 207 (1938), should hesitate to enforce repurchase options when the interested party has apparently ignored these principles. 
if the valuation mechanism was not manipulated; nor the employee's resignation precipitated, by persons standing to gain from the repurchase, the contract could justly be enforced according to its terms. But if it appears that the price offered is not what the parties intended, or that the optionee's termination of employment was engineered in order to shift income to the option holder, an abuse is indicated. ${ }^{36}$ To enable the employee to demonstrate abusive conduct. the corporation should cease to be favored with a presumption that its action:discharging an employee, establishing a valuation for accounts-were designerl to achieve valid business goals. ${ }^{37}$ Since the agreement itself is one-sided, and since the corporation will have superior access to critical facts, it should assume the burden of proving corporate good faith whenever the optionee's evidence, together with a strict construction of the option holder's contractual powers, suggests a reasonable likelihood of abuse.

If the corporation is required but unable to prove its good faith, a suitable remedy must be fashioned for the injured employee. Courts in the past, on finding an option unenforceable, have simply denied specific performance to the option holder, ${ }^{39}$ a solution ill-suited to the employee's peculiar situation. Only when liquidation is imminent or an outside market exists for the stock will withholding specific performance leave him in a position to realize the intrinsic value of his shares. More commonly, he will simply be "locked in" a hostile close corporation whose stock is unsalable. ${ }^{40}$ On the other hand, if he does sell his shares, one of the essential and universally recognized purposes of the option agreement-preventing stock transfers to outside interests ${ }^{41}$-may be defeated. To preserve the expectations of both parties to the option, the courts

36. Cf. Helms v. Duckworth, 249 F.2d 482 (D.C. Cir. 1957) (intent to frustrate renegotiations); Lawrence v. Sudman, 70 F. Supp. 387 (S.D.N.Y. 1945) (value of ships on corporation's official books some $\$ 300,000$ less than on its tax books when employeestockholders discharged under book-value option pending liquidation; this amount subsequently distributed to controlling stockholders).

37. The presumption in the corporation's favor is strong. Bad faith has not been found in many cases where the facts might easily have led to a different conclusion. See, e.g., Lawrence v. Sudman, supra note 36 (plaintiff discharged on Friday, rehired on Monday after option had been exercised; large liquidating dividend subsequently declared to majority shareholders) ; Krauss v. Keuchler, 300 Mass. 346, 15 N.E.2d 207 (1938) (manipulating accounts-receivable valuation) ; New Eng. Trust Co. v. Abbott, 162 Mass. 148, 153, 38 N.E. 432, 438 (1894) (valuation of stock at closed meeting; no justification given for figure reached).

38. The court must first interpret the agreement of the parties to ascertain what provision they made for the prevailing situation. If the court finds that the parties made no provision for the conduct that has occurred, it may "fill the gap" by the process of construction. See 3 Corbin, Contracts $\$ 534$ (1951). This is substantially the process followed by the court in Helms v. Duckworth, 249 F.2d 482 (D.C. Cir. 1957).

39. See, e.g., Ingalls Iron Works Co. v. Ingalls, 256 Ala. 124, 53 So. $2 d 847$ (1951); Brown v. Little, Brown \& Co., 269 Mass. 102, 168 N.E. 521 (1929).

40. See Hornstein, supra note 29 , at 1049 . On the unfavorable position of the outside shareholder in the close corporation, see generally Symposium-The Close Corporation, $52 \mathrm{Nw}$. U.L. Rev. 345, 384-96 (1957).

41. See note 1 supra. 
should grant specific performance despite the option holder's bad faith, but should not enforce a repurchase price which would enable the dominant shareowners to derive windfall profits. When misconduct is limited to option-holder abuse of the price-fixing formula, a correct figure under the formula should be substituted. ${ }^{42}$ But if the complaining employee was discharged so that his shares could be repurchased, he should be awarded their intrinsic value irrespective of the terms of the option.

Admittedly, this award of current, intrinsic value would sometimes overcompensate the employee for past services. To calculate damages with more precision, however, would be to encounter nigh-insurmountable difficulties in ascertaining prospective gains on the stock, so that the portion of those gains allowable for services rendered could be established. ${ }^{43}$ Absent a specific cutoff date, the option would presumably run until the employee's death. Although actuarial tables could be used to estimate this period, an accurate forecast of corporate profits, much less of dividends, would be unlikely. Similarly, a prediction of future capital gains under valuation clauses subsuming them would be fraught with inaccuracies. If a fixed-term option is assumed, a theoretically perfect computation of damages would rest on a mere guess as to when the employee would dispose of his shares, what his profit or loss on the sale would he, and how much he would ultimately receive in dividends. Because a determination of purely compensatory damages is thus impractical, and because corporate bad faith here underlies the premature exercise of the option, whatever windfall arises should accrue to the employee. ${ }^{44}$

Although the current, intrinsic value of a closely-held corporation's stock is difficult to determine, recognized valuation formulas applicable to readily obtained data are available for this purpose. ${ }^{45}$ Faced with a particular corporation and a given occasion for appraisal, the expert can choose accurately among a number of alternative methods for establishing the worth of the company's

42. See Moser v. Keller, 303 S.W.2d 135 (Mo. 1957) (extensive court computation of bock value necessary to carry out intent of parties). Some courts have inferred an intent to repurchase at intrinsic value in spite of specific contract terms. See Helms v. Duckworth, 249 F.2d 482 (D.C. Cir. 1957).

43. A converse problem might arise if an employee who had received stock in a newlyfurmed company in lieu of a high salary resigned before receiving dividends. Since dividends in later years might well be regarded as partially compensating him for services performed at the firm's inception, the employee might attempt to claim in quantum meruit for the fair value of his work. Cf. Humphrey v. Johnson, 73 Ind. App. 551, 127 N.E. 819 (1920). Unless there is evidence of bad faith in either procuring the resignation or withholding dividends, such a claim anpears without merit. Proof of "just compensation" borders on the esoteric, if. Patton v. Commissioner, 168 F.2d 28 (6th Cir. 1948) ; moreover, the employee may be said to waive any rights to future profits when he leaves voluntarily.

44. An award of intrinsic value also ignores the possibility that the employee will mitigate damages by taking another job. A comparison of his compensation on his new job with that on his old could prove difficult since in his new job he would be unlikely to receive stock with identical potentialities for gain or loss.

45. For a sample valuation problem, see Eisele, Valuation of Closely Held Stocks, 5 W. KEs. L. Rev. 37, 58-61 (1953). 
shares. ${ }^{46}$ To avoid an expensive "battle of experts" when repurchased stock is at issue, ${ }^{47}$ the valuation problem should be referred to a special master, himself an expert in the field. ${ }^{48} \mathrm{He}$ should have access to all factual evidence which he or the parties deem relevant, but should draw his own conclusions, not weigh the testimony of other experts. ${ }^{49}$

In summary, the fact that close corporations find the repurchase option useful should not deter the courts from scrutinizing its use when gain is diverted from an employee to dominant shareholders. The difficulties of assessing damages and valuing closely-held stock need not and should not frustrate the attainment of equitable results. More important, strict judicial supervision of reacquisitions would encourage the careful drafting of option agreements generally and pricing formulas particularly, so as to eliminate temptations for abuse and causes for complaint. ${ }^{\overline{0} 0}$

46. Dakin, Valuation of Close Corporations, 34 ChIcago BAr RecoRd 421 (1953); see 1 Dewing 280-307.

47. One firm which specializes in valuation of close corporation stocks charges from $\$ 50$ to $\$ 300$ per day for the preparation of a report. A detailed report on a complicated corporation may cost as much as $\$ 12,000$. The company's fee for providing expert testimony is $\$ 300$ per day. Letter to the Yale Law Journal, Dec. 23,1958 , on file in Yale Law Library.

48. For the dilemma of a judge faced with conflicting expert testimony, see, c.g., Whittemore v. Fitzpatrick, 127 F. Supp. 710 (D. Conn. 1954) (analysis of factors influencing stock valuation in a gift tax case).

49. Admittedly, the master's finding would simply be an expert opinion and subject to the criticism generally leveled at the "all factors" approach. See, e.g., Johnson, Shapiro \& O'Meara, Valuation of Closely-Held Stock for Federal Tax Purposes: Approach to an Objective Method, 100 U. PA. L. REv. 166, 167-69 (1951); Rice, The Valuation of Close Held Stocks: A Lottery in Federal Ta.tation, 98 U. PA. L. Rev. 367, 371-77 (1950). In this situation, however, he would be disinterested, and possibly in a better position to justify his finding than a judge faced with a choice among several expert views.

A broad right of appeal from the master's finding would involve many of the evils of the battle of experts. Thus, in a case in which the parties themselves had provided a formula which included appraisal if disagreement occurred as to book value, the court summarily dismissed an attempt to appeal the findings. Abbott v. Abbott Motors, 11.3 N.Y.S.2d 213 (Sup. Ct. 1951).

50. The draftsman may wish to provide different repurchase prices for different contingencies, make provision for periodic renegotiations of price, or set up an appraisal procedure which takes account of going-concern value. See generally O'Neal, supra note 1, at 773-816. Since the benefits of a carefully drafted option which is fair to both parties seemingly outweigh any possibility of gain from an ironclad agreement specifically providing for arbitrary dismissals, it appears likely that this course would be followed.

Another possible effect might be reluctance to issue stock to employees. This does not seem undesirable, as many of the legitimate purposes for issuing stock to employees subject to restrictions can be achieved by other means which do not expose the employeu to the risks of share ownership. E.g., profit sharing plans established by depositing shares in trust, see Washington \& RoThschILD 488-502 (Chrysler Corp. plan); prolit sharing contracts, see id. at $456-63$. 